\title{
Chapter 7 \\ Patriating Our Head of State: A Simpler Path?
}

\author{
Dean R Knight
}

\subsection{Introduction}

The debate about whether New Zealand should become a republic risks becoming a mare's nest. The idea of cutting ties with the monarchy is engrafted with a myriad of other constitutional reforms from budding constitutional architects: a codified constitution; codification - or removal - of the reserve powers; an entrenched Bill of Rights; resolving the status of the Treaty of Waitangi; sorting out the flag, the national anthem. The list goes on. It is no wonder therefore that little progress has been made on this front since the time of the last conference, Building the Const $i$ tution, in 2000, despite the fact that three of our most recent Prime Ministers have all described moving to a republic as being "inevitable". 1

Like one of the speakers at the earlier conference, I suggest the republican project is much simpler. ${ }^{2}$ At its heart, it involves changing our Head of State from a hereditary monarch based abroad to a local, chosen by us. The only consequential change also needed is the substitution of a new collective entity representing the state, government and people of New Zealand for the present

Dean R Knight is a Senior Lecturer in the Faculty of Law, and an Associate of the New Zealand centre for Public Law, Victoria University of Wellington. He is also Constitutional Advisor to the Republican Movement of Aotearoa New Zealand. The author would like to thank subject to the usual caveat of his ultimate responsibility, Lewis Holden and David Friar for comments and feedback on an earlier version of this paper, along with David Bullock and Conrad Reyners for research and other assistance.

${ }^{1}$ For example, Bolger (1994); Clark, reported in The Dominion (2002); Clark (2009b); and Key, reported in Smith (2008).

${ }^{2}$ Ladley (2000).

D.R. Knight $(\bowtie)$

Faculty of Law, Victoria University of Wellington, PO Box 600, Wellington 6140, New Zealand e-mail: Dean.Knight@vuw.ac.nz 
Crown. Two changes. No more. No less. The minimum change necessary in order to patriate - or, rather, to complete the patriation of our Head of State.

This task is even easier because New Zealand is presently, as Professor Brookfield described us, a "de facto" republic. ${ }^{3}$ It might even be appropriate to describe the Governor-General as our "de facto Head of State" (although I nervously note the grief that recently arose in Canada when similar language was deployed). ${ }^{4}$ We need look no further than the office of the Governor-General, and people who have and will occupy it, for our new indigenous Head of State.

We can simply promote the Governor-General from the Sovereign's delegate to the people's representative in his or her own right. This move would do no more than reflect who, in reality, exercises the day-to-day functions of the Head of State. Nor do we need to invent a new title or style. It is not essential that the new Head of State assume the mantle of "President". The title of Governor-General could continue - or an alternative title could be adopted.

It will be obvious that I am a fan of "soft republicanism". My commitment is to patriating the office of the Head of State, that is, cutting ties with the monarchy. We should pursue that passionately, but in a way that does not upset or alter the other constitutional structures and delicate power balances. I remain agnostic about other constitution reforms, even those touching the powers and functions of the Head of State. I do not detect strong dissatisfaction with the other arrangements and see little need to pursue a broader full republican agenda that would fundamentally change the nature and powers of the Head of State, Parliament or government. While the status and influence of the Treaty in our constitutional dynamic continues to be debated, settling the place of the Treaty is not an essential pre-condition to changing our Head of State. The existing status quo can be preserved in a way that allows the kōrero about the legal and constitutional place of the Treaty to continue to develop. The significance of the Treaty in our constitutional fabric needs to be recognised in any transition from the Crown to a republic. But its significance is relational, not static. In my view, the novation of Treaty rights and responsibilities (something that has occurred several times already) does not affect the fulfilment of those rights and responsibilities.

At the end of the day, trying to do too much and attempting to fix every potential constitutional gremlin or pursuing a "Rolls Royce" constitution is an impossible and unnecessary task. It is merely an excuse for delaying an important step in the evolution of the New Zealand identity and nationhood. It is inconsistent with the Kiwi approach to constitutional reform. ${ }^{6}$ Our approach to constitutional reform has been described as "ad hoc pragmatism"7 or "pragmatic

\footnotetext{
${ }^{3}$ Brookfield (1995), p. 317.

${ }^{4}$ Canada's Governor-General, Michaëlle Jean, once described herself as the "Head of State", and was later rebuked by Canadian Prime Minister Stephen Harper: Clark (2009a).

${ }^{5}$ Ladley (2000), p. 268.

${ }^{6}$ The more colloquial term "Kiwi" sometimes better conveys the sentiment in this context.

${ }^{7}$ Palmer (2007), p. 571.
} 
evolution". 8 The soft republicanism approach to reform of the office of Head of State is therefore consistent with how we have made and moulded our customary constitution to date.

Armed with a minimalist vision of the republican question, the usual questions why? who? what? when? how? - become less intimidating and less contentious. I explore in more detail the approach outlined above, looking at these questions through the eyes of a soft republican.

\subsection{Why?}

In some respects, the why arguments are the least interesting element of this debate. At their extremes, they are trite and well-rehearsed ${ }^{9}$ Like the recent Battle for Kelburn Park between Alf's Imperial Army and New Zealand Republic@Vic, ${ }^{10}$ recital of the arguments may create an amusing dogfight with many sparks and much barracking but it is unlikely to lead to a concession, consensus or constructive advancement of the issue.

For the record, the arguments for a republic are usually centred on the following:

- Independence (New Zealand is an independent country and should have a Head of State of its own);

- Nationhood (our Head of State should reflect our unique sense of nationhood and royal linkages are out-dated); and

- Democratic evolution (our constitutional arrangements should be more democratic).

In contrast, the monarchists defend the status quo by pointing to the following:

- The Head of State has already been patriated (the Queen is the Queen of New Zealand);

- There are dangers in changing (concerns that republics are unstable; viz, "if it aint' broke, don't fix it"); and

- The continuing benefits of royal links (British linkages and protection).

Proponents of full republicanism will also proclaim that our constitution is broken and needs to be fixed. More democracy, more certainty, more codification. That is why we should reform our constitution and become a republic. But the why question is harder for proponents of soft republicanism, who are perhaps less visible in the royalists-modernists debate. Soft republicans are not willing to concede that the existing legal structures and processes are defective. The model of the de facto

\footnotetext{
${ }^{8}$ Constitutional Arrangements Committee (2005), para 26 and Joseph (2007), p. 139.

${ }^{9}$ Hayward (2000), p. 261; Stockley (1996a), p. 61. See also www.republic.org.nz/reasonsforarepublic and www.monarchy.org.nz/modern.html.

${ }^{10}$ www.republic.org.nz/node/1419.
} 
republic is generally working well, save for the incongruous symbolism that cloaks it.

But symbols and identity matter. As a symbol, the monarchy sits uncomfortably with the vision of ourselves as a progressive, egalitarian South Pacific nation. The monarchy operates as a significant constraint on our ability to develop further our sense of nationhood. The British anchor has served us well in the past, but we are now communities with different demographics, different cultural mixes, and different aspirations. While Governors-General are charged with cultivating some of this symbolism, ${ }^{11}$ their ability to present the office of Head of State as a mirror of the values and aspirations of peoples of New Zealand is dampened by their subordinate status as a representative of the Royals.

It is significant that the role of the de facto Head of State has evolved significantly over time. ${ }^{12}$ Every Governor-General since 1967 has been a New Zealander. Women have occupied the post. Greater ethnic diversity has been evident of late, with Māori and Pacific appointees. Governors-General now regularly represent New Zealand internationally. The current Governor-General regularly expresses greetings in Te Reo Māori and New Zealand Sign Language. Sir Anand Satyanand also now issues a "New Year's Day" message, with content which seems much more relevant to New Zealanders than the Queen's Christmas message. In many ways, the evolution of the office tracks our own evolution as a nation. But there are limits to the extent to which the office can continue to develop when it is in anchored by a foreign pedigree. Radical change is not needed, but continual evolution will allow the office-holders to ensure that the role continues to represent and reflect the values and expectations of a modern-day New Zealand.

I should also record that the evolution of the symbols of the office and nationhood do not require us to expunge the symbols of our British heritage. Here, I may cause some angst for some more militant republicans. In my view, the path to the republic and beyond is one of blending our heritage with our modernity. Over time the now will probably become more dominant than the past as we reinvent and recast our symbols.

\subsection{Who?}

The question of who should be the Head of State under a republic also seems to attract a lot of interest. Again, soft republicans say there is little need to deviate from the recent pattern of Governors-General. They have served us well when discharging the ceremonial, community and constitutional functions of the office. ${ }^{13}$

\footnotetext{
${ }^{11}$ Satyanand (2010a).

${ }^{12}$ Tizard (1993); Cartwright (2001); McLean (2006); and Satyanand (2010b).

${ }^{13}$ Palmer and Palmer (2004), pp. 54-55.
} 
Former judicial appointment is less important than it was in the formative days of our Mixed Member Proportional electoral system (MMP). The conventions around government formation and the role of the de facto Head of State are now quite sophisticated and readily understood. While the constitutional functions remain significant, a senior civil servant or leader of a non-government organisation who is familiar with the constitutional landscape and capable of receiving and acting on advice is well-placed to discharge these functions. The Prime Minister has already signalled that, for the appointment of a new Governor-General in 2011, we may see a departure from the practice of appointing someone with judicial background. $^{14}$

While the identity of potential office-holders makes headlines, the means of appointment is the more important question: direct election of the Head of State by the public or indirect appointment by the Parliament. It is this issue, and the polarised debate about it, that probably killed the Australian republican debate and plebiscite in $1999 .^{15}$

What is clear is that the present status quo for selection of the Sovereign is obviously unsatisfactory. As noted earlier, the hereditary and discriminatory appointment process for the monarch is an anathema to New Zealanders. It is biased towards males and is antipathetic towards Catholics. ${ }^{16}$ We will almost certainly never see a Kiwi fill the role of monarch. That is a shame for New Zealanders generally. But it must be a major disappointment for Māoridom; under the present arrangements, there is no real prospect of the New Zealand Head of State being someone Māori.

The appointment process for the Sovereign's delegate, the Governor-General, is also too loose. The Governor-General is formally appointed by the monarch under the Letters Patent. ${ }^{17}$ In reality, the selection of the Governor-General is the responsibility of the government of the day and the Prime Minister. ${ }^{18}$ Under our cardinal constitutional convention, the Monarch is expected to act on the advice of her responsible advisors - although, as a courtesy, the proposed appointee is canvassed with Her Majesty first. There remains some uncertainty about cross-party involvement in the selection process. Some observers suggest there is a constitutional convention of consultation, at least with the Leader of the Opposition. ${ }^{19}$ However, whether this convention exists and/or has been honoured remains something of a mystery. There have been instances where it appears some parties were not consulted and did not favour the appointment of the candidate. ${ }^{20}$

\footnotetext{
${ }^{14}$ Radio New Zealand (2011).

${ }^{15}$ Higley and Evans Case (2000); Stockley (1998).

${ }^{16}$ Act of Settlement 1701 and Royal Marriages Act 1772. See Feldman (2004), para 3.87.

${ }^{17}$ Letters Patent Constituting the Office of Governor-General 1983, cl 2.

${ }^{18}$ Cabinet Office (2008), para 2.5.

${ }^{19}$ Palmer and Palmer (2004), p. 53.

${ }^{20}$ It is understood that the convention was not followed for the appointments of Sir Keith Holyoake (1977), Sir Paul Reeves (1985) and Sir Michael Hardie-Boys (1996).
} 
The present appointment process model for the Governor-General could simply be rolled over. But the looseness of the appointment process and possibility for contentious appointments risks undermining the essential apolitical and unifying elements of the office. I favour minor tweaks to the appointment process to avoid this, specifically, through the formalisation of the present best practice around appointments. Indeed, the Republican Movement recently proposed similar changes to the Governor-General's appointment as it stands now, ${ }^{21}$ and the ideas were raised in recent debates on the Governor-General Bill. ${ }^{22}$ The nature of the functions of the Governor-General as a guardian of the political and parliamentary process suggest there should be broad acceptance amongst the political players. That is, there should be practical consensus amongst the parliamentarians about the appointment of the Governor-General. I favour a model based on a resolution supported by a super majority within the House.

The $75 \%$ majority found in s 268 of the Electoral Act 1993 is an obvious template for appointment. But I worry it is a remnant of the two-party first-pastthe-post (FPP) days. If we are serious about the appointment having a widespread parliamentary support, then the super majority needs to recognise the role of minor third parties too. One option is to adopt the $75 \%$ MPs $/ 50 \%$ parties super-supermajority approach already found on the statute book. ${ }^{23}$ That is, a provision such as this:

\#\# Appointment of the Governor-General

(1) The Governor-General is appointed by resolution of the House of Representatives.

(2) No resolution may be made by the House of Representative under subsection (1) unless:

(a) the resolution is agreed by at least half of the parliamentary leaders of all political parties represented in Parliament; and

(b) the members of Parliament of the political parties whose parliamentary leaders agree with the resolution comprise at least 75 per cent of all members of Parliament.

Concerns about minor parties holding the process to ransom are, I think, misplaced. But I would not quibble too much about the nature of the super majority provision. The principle of widespread parliamentary support is more important.

Of course, more dramatic change to the selection process is also possible, whether it be formalised voting systems in the House or some form of public involvement in the nomination process. But, for a soft republican, these are an unnecessary complication. Direct election, through a popular poll, is another possibility - and one of the options posed in Keith Locke's recently defeated Head of State Referenda Bill. While experience abroad shows that this is a workable mechanism for appointment of a Head of State, ${ }^{24}$ one wonders if it is a

\footnotetext{
${ }^{21}$ Republican Movement of Aotearoa New Zealand (2010).

${ }^{22}$ Ultimately, questions of appointment were ruled to be out of scope of the Bill: Government Administration Committee (2010).

${ }^{23}$ Electoral Finance Act, s 146(1)(c) (now repealed).

${ }^{24}$ For an excellent discussion of the Irish President and direct election, see Harris (2009b).
} 
step too far for pragmatic New Zealanders and risks providing false hope for the electorate of some massively revamped - and politicised - Head of State role. Again, soft republicans see this as an unnecessary complication and risk.

The final element of the who question is the brand: what should be the name or style for new Head of State? As mentioned earlier, many assume the mantle of President is inevitable. But the constitution reformer's brush is not so limited. We can call them whatever we want. The language of President would seem to be awkward and connotes more dramatic reform.

A truly soft republican might therefore suggest that "new" title for the Head of State continue to be the same as the old title: Governor-General. While unprecedented, retaining the title of Governor-General minimises any change and is consistent with the brief of merely entrenching the reality of our Head of State role. Some might, though, worry that the retention of the title implicitly retains links to the Royals and does not do enough to repudiate the Governors-General's now subordinate status.

Another option might be adopting the generic title "Head of State". While perhaps lacking in grandeur, such a label would not be objectionable. Our Samoan cousins adopted this Head of State style in their constitution, but have also adorned it with the indigenous title "O le Ao o le Malo". ${ }^{25}$ That approach seems sensible. One might expect over time the office of Head of State or Governor-General might be gifted a Te Reo title by Māoridom that may capture the essence of the revitalised role. $^{26}$

\subsection{What?}

The what question - the question of the powers, functions and duties of the Head of State - is easy for the soft republicans. The new Head of State will be imbued with exactly the same functions, powers and duties as the monarch. Reforming legislation can make this clear with a generic statement detailing the transfer of power on these terms. The prerogative powers of the monarchal Head of State will continue with the new indigenous Head of State. This is the most modest and efficient approach. A more complex and time-consuming task is to create a catalogue of all the monarch's powers and to provide for specific transfer in each and every case. ${ }^{27}$ At least in the first instance, I think this is an unnecessary and

\footnotetext{
${ }^{25}$ Samoan Constitution, s 16.

${ }^{26}$ The current Te Reo translation of the Governor-General's position is Te Kāwana Tianara o Aotearoa.

${ }^{27}$ See, for example, the present Law Foundation-funded project being undertaken by Dame Alison Quentin-Baxter and Professor Janet McLean (Law Foundation (2009)) to identify all the powers and functions of the monarch.
} 
time-consuming task. Generic transfer is sufficient in my view, but the legislation might consider setting up a process for legislative references to be amended in due course following the ultimate transition of power.

More radical reformers will want to consider stripping the new Head of State of some of the prerogative powers or codifying the constraints on their exercise. Concerned about the (largely theoretical) power vested in the monarch and de facto Head of State today, they are worried that it will be exercised in a counterdemocratic fashion. Our constitutional conventions, values and culture ensure, however, that this power is exercised consistently with the democratic imperative. We might consider codifying those conventions, ${ }^{28}$ but this unnecessarily risks misstating them or making them overly rigid. For example, the conventions around government formation have evolved consistently with the evolution of our democratic systems under MMP and are generally thought to be working well.

We might also consider removing the reserve powers of the Head of State, as well as vesting the prerogative powers in those constitutional actors who in reality exercise them as responsible advisors. Professor Bruce Harris has provided a blue-print for such change. ${ }^{29}$ Again, though, the soft republican remains agnostic. Such amendment has the potential to change the present political and constitutional balance within our system. The Governor-General's powers to act contrary to advice - the power to sack a Prime Minister, the power to refuse Royal Assent, and so forth - are dramatic but theoretical. We expect it is unlikely that they will ever be needed, but this theoretical possibility gives the political players some reason to be circumspect and not to test the outer boundaries of constitutionality.

The Crown is a metonym for the State or executive government. ${ }^{30}$ The what question therefore also captures the reformation of the concepts of the Crown in right of New Zealand and the Realm of New Zealand. A move to a republic requires the transfer of power and responsibility from the Crown and to a similar entity, such as the "Republic of New Zealand", "Independent State of New Zealand" or "Republic of Aotearoa New Zealand, known as New Zealand". Again, soft republicans do not see this reformation as a significant hurdle. Reforming legislation need only create the State or entity and imbue it with the same rights and responsibilities as the Crown in right of New Zealand formerly possessed.

At this point, we must confront the effect of republicanism on the Te Tiriti o Waitangi and the on-going Treaty relationship. There has been much speculation about the impact of a change of the Head of State on the legal and political status of the Treaty. Many doomsayers think the Treaty cannot survive any change. Others think a change to a republic is an ideal window of opportunity to improve and

\footnotetext{
${ }^{28}$ See for example Jamaica (Constitution) Order in Council 1962.

${ }^{29}$ Harris (2009a), p. 285.

${ }^{30}$ Town Investments Ltd v Department of the Environment [1977] 1 All ER 813 at 831; and Cox (2002a), p. 237.
} 
enhance the status of the Treaty. Some, including the Māori Party, think that any constitutional change must be Treaty-centred. ${ }^{31}$

Again, soft republicans warn against trying to do too much constitutional reform and overcomplicating the reform of the Head of State. It is legally and constitutionally possible to ensure that the Treaty retains the same legal and constitutional status within the new republic as it did within the monarchy. As Professor Stockley noted: "The Treaty obligations have already passed from the Queen in right of Britain to the Queen in right of New Zealand. If they have been transferred once they can be transferred again." 32 Even ardent monarchists concede a change to a republic would not alter the status of the Treaty. ${ }^{33}$ The reality is that New Zealand's executive government is nowadays responsible for discharging Queen Victoria's original compact with iwi and hapū. ${ }^{34}$ That will continue under a republic, with the State assuming those responsibilities.

Beyond the legal status, there remains the question of the more intangible symbolism and associated "honour of the Crown" in relation to the Treaty. Soft republicans are anxious not to undermine these important elements in any transition. As was acknowledged earlier, symbolism matters. And it is often said this is especially important to Māoridom. We must not only ensure the smooth transfer of the legal duties, but also the spirit of the Treaty. Some trust is needed, but it seems extremely unlikely a modern-day state would attempt to repudiate the treasured "honour" of the former Crown. The lodestar of minimalism and continuity that lies at the heart of soft republicanism must surely ensure that the extra-legal status of the Treaty is also preserved.

This can be fortified in republican legislation. Treaty obligations will be expressly transferred to the new republic, without promoting or diminishing its present legal status or preventing its continual evolution. Reforming legislation styled in soft republican form - need not specifically refer to the Treaty because it would be captured within the generic transfer of powers and responsibilities. However, given its special importance in modern-day society, it would be desirable for the Treaty to be specifically mentioned, both in terms of its present legal transition (in the clause transferring the Crown's powers and responsibilities) and its historic importance in our constitutional heritage (in a preamble noting our previous constitutional milestones).

Finally, the what question requires us to address whether the change to our Head of State needs to change the constitutional position of the Niue and the Cook Islands. These self-governing states form part of the Realm of New Zealand,

\footnotetext{
${ }^{31}$ Katene (2010).

${ }^{32}$ Stockley (1996b), p. 101. See also Brookfield (1995).

${ }^{33}$ Cox, then Chairperson for Monarchy New Zealand, quoted in Milne (2004). See also Cox (2002b), p. 29.

${ }^{34}$ For a discussion of the meaning of the Crown in the context of the Treaty, see McLean (2008) and Cox (2002b).
} 
along with Tokelau and the Ross Dependency. ${ }^{35}$ Possible solutions have been proposed which might see these self-governing states follow New Zealand in becoming a republic or their translation into their own realms. ${ }^{36}$ This aspect need not halt our moves to patriate our Head of State.

\subsection{When?}

The move to the republic has been cursed by many as being "inevitable", as was noted at the outset. Rather than fortifying the likelihood of the republic, this has nullified momentum. Inevitable seems to be code for "yes - but not on my watch".

The defeat of Keith Locke's Head of State Referenda Bill at its first reading in early 2010 should not be taken as meaning there is no parliamentary appetite for the commencement of a move to a republic. ${ }^{37}$ A number of factors probably factored into its demise:

- Timing (the referenda proposal would have interfered with the staged referenda on MMP);

- Sponsor (some MPs appeared uncomfortable supporting constitutional change sponsored by an Opposition member);

- Text (the Bill that languished in the ballot for nearly 9 years was intended to catalyse the debate only and might have benefited from some fresh re-drafting); and

- Recession (a government wanting to be seen to be engaged in fixing bigger, more immediate problems).

There still appears to be some staunch royalist support within Parliament, particularly amongst the National Party. However, the debate of Locke's Bill had some positive benefits for the republican movement, with the creation of a crossparty parliamentary caucus on the issue and increasing engagement with the issue by parliamentarians.

The pragmatic approach to constitutional reform associated with soft republicanism looks to the end of the reign of Queen Elizabeth II as an important opportunity. While support for the republic continues to increase, particularly amongst younger generations), there still remains some fondness towards our present Sovereign. A pragmatic compromise might be completing necessary processes in order to become a republic, but deferring its commencement until the passing of our present monarch. A possible formula, based on the outcome of a referendum, might look as follows:

\footnotetext{
${ }^{35}$ Letters Patent Constituting the Office of Governor-General of New Zealand (SR 1983/225), cl 1.

${ }^{36}$ Townend (2003).

${ }^{37}$ Head of State Referenda Bill 2009 (defeated on 21 April 2010 by 68 votes to 53).
} 
\#\# Commencement

(1) Subject to subsections (2) and (3), this Act comes into force 2 days after the date on which it receives the Royal assent.

(2) If the Chief Electoral Officer makes a positive referendum declaration, Part 2 (Transformation to Republic) of this Act will come into force:

(a) on the death of Queen Elizabeth the Second; or

(b) if Queen Elizabeth the Second dies before a positive referendum declaration is made, 6 months after the date of the declaration.

(3) If the Chief Electoral Officer makes a negative referendum declaration:

(a) Part 2 (Transformation to Republic) does not come into force; and

(b) this Act is deemed to be repealed.

\#\# Interpretation

(1) In this Act, unless the context otherwise requires,-

positive referendum declaration means a declaration under Part 3 (Referendum on Republic) of this Act that the proposal favouring the introduction of the republic as provided in this Act is carried;

negative referendum declaration means a declaration under Part 3 (Referendum on Republic) of this Act that the proposal favouring the introduction of the republic as provided in this Act is not carried;

Of course, that does not mean we can rest on our laurels. It would be preferable for us to have all the necessary arrangements in place so that the republic can take effect immediately, without more. The risk of not acting now is that we might be caught on the hop by the passing of Queen Elizabeth. While the soft republican approach does not require extensive legislative and structural preparations, it goes without saying that any change required popular support, at least through a plebiscite - which takes some time.

\subsection{How?}

It has been suggested that it might be technically possible to become a republic with a simple amendment to the Constitution Act promulgated through ordinary legislation. ${ }^{38}$ But nowadays there does not seem to be any serious disagreement about the fact that a referendum is needed for any change. The change needs to have popular support to have moral legitimacy. Putting the issue to a referendum also circumvents the theoretical arguments about Parliament's capacity to effect such a revolutionary change. ${ }^{39}$ A referendum ensures a "technical revolution" takes place. ${ }^{40}$ The question of whether there is a need for majorities in referenda of both general and Māori rolls, as has been suggested ${ }^{41}$ seems to be driven out of

\footnotetext{
${ }^{38}$ Stockley (1996b), p. 98.

${ }^{39}$ See Brookfield (1995); and Cooke (1996). Compare Stockley (1996b) and Joseph's discussion of "autochthony", Joseph (2007), p. 478-485.

${ }^{40}$ Brookfield (1995).

${ }^{41}$ Brookfield (1995), p. 317 and Stockley (1996c).
} 
concern for the future status of the Treaty. Such arguments carry less weight for a change grounded in minimalism and continuity - where the Treaty relationship continues unaffected.

Assuming the constitutional how is answered by a referendum, the practical how remains at large. Undoubtedly, support for the republic both amongst parliamentarians and the polity continues to grow. But more rapid progress is stymied by misinformation and misapprehension about the nature and magnitude of any change. Occasions such as this provide some opportunity for the path to the republic to be canvassed. But broader public education and involvement is required, if we are serious about attaining republic status. Options such as a formal constitutional convention or an eminent leaders group have been proposed. ${ }^{42}$ The constitutional arrangements select committee process petered out somewhat. ${ }^{43}$ Oddly, republican issues were not included in the much anticipated constitutional review, which is more focused on the status of the Treaty, Māori representation and other electoral matters. ${ }^{44}$ Processes which seek to solve every possible constitutional issue are doomed to failure and only serve to delay further any progress towards a local Head of State. If a blue-print is needed for the public to better understand the implications of a republic, then there might be a delicious irony in a Royal Commission being charged with examining that single issue. ${ }^{45}$ There is some weight in constitutional reform of this sort being deliberated on by wise people, so that the public can be given comfort that any move is sound and appropriate.

\subsection{Conclusion}

We are presented with two different models for the republic. An excessive "Rolls Royce" model - a complicated approach that lets the constitutional architects loose to try and fix each and every constitutional soft-point within the reformer's window of opportunity. Or we can take seriously the pressing need to patriate our Head of State in order that our identity and nationhood can continue to evolve. We need only promote the Governor-General from being a de facto Head of State to a real Head of State - same powers, same functions, same responsibilities, same house, same Treaty responsibilities. A Toyota Corolla, a minimalist's republic will be fine.

\footnotetext{
${ }^{42}$ Moore (2008).

${ }^{43}$ Constitutional Arrangements Committee (2005). Nothing much came of the report, particularly as the process of review failed to attract cross-party support (National and New Zealand First refused to participate).

${ }^{44}$ English and Sharples (2010).

${ }^{45}$ Compare with the Royal Commissions on the Electoral System and on Auckland Governance.
} 


\section{References}

Bolger J (1994) Address-in-Reply Debate, 24 March

Brookfield FM (1995) Republican New Zealand: legal aspects and consequences. NZ Law Rev:310

Cabinet Office (2008) Cabinet manual

Cartwright S (2001) The role of the Governor-General. New Zealand Centre for Public Law Occasional Paper

Clark C (2009) A hot debate about Head of State. Globe and Mail Toronto, 10 October

Clark H (2009) Valedictory Address to Parliament, 8 April

Constitutional Arrangements Committee (2005) Inquiry to review New Zealand's existing constitutional arrangements. August. New Zealand House of Representatives, Wellington

Cooke R (1996) The suggested revolution against the Crown. In: Joseph PA (ed) Essays on the constitution. Brookers, Wellington, p 28

Cox N (2002a) The theory of sovereignty and the importance of the Crown in the realms of the Queen. Oxford Univ Commonwealth Law J:237

Cox N (2002b) The Treaty of Waitangi and the relationship between Crown and Maori in New Zealand. Brooklyn J Int Law 28:123

English B, Sharples P (2010) Government begins cross-party constitutional review. Available at: www.bahive.govt.nz.release/govt-begins-cross-party-constitutional-review

Feldman D (ed) (2004) English public law. Oxford University Press, Oxford

Government Administration Committee (2010) Report on Governor-General bill

Harris B (2009a) Replacement of the royal prerogative in New Zealand. NZ Univ Law Rev 23:285

Harris BV (2009b) The Irish President, the New Zealand Governor-General and the Head of State in a future New Zealand republic. NZ Law Rev:605

Hayward J (2000) Who should be Head of State? In: James C (ed) Building the constitution. Institute of Policy Studies, Wellington

Higley J, Evans Case R (2000) Australia: the politics of becoming a republic. J Democr 11:136

Joseph PA (2007) Constitutional and administrative law in New Zealand, 3rd edn. Brookers, Wellington

Katene R (2010) Speech on Head of State Referenda Bill, 21 April

Ladley A (2000) Who should be Head of State. In: James C (ed) Building the constitution. Institute of Policy Studies, Wellington

Law Foundation (2009) Researching royal role in NZ. Available at: www.lawfoundation.org.nz/ news/read.php?i=63. Accessed on 10 March 2009

McLean G (2006) The Governors: New Zealand's Governors and Governors-General. Otago University Press, Dunedin

Mclean J (2008) "Crown Him with Many Crowns": the Crown and the Treaty of Waitangi. In: Geiringer C, Knight DR (eds) Seeing the world whole: essays in honour of Sir Kenneth Keith. Victoria University Press, Wellington

Moore M (2008) Banana republic risk, without the bananas. The New Zealand Herald, 14 January

Milne J (2004) The people vs the Crown. Sunday Star Times, 30 May

Palmer M (2007) New Zealand constitutional culture. NZ Univ Law Rev 22:565

Palmer G, Palmer M (2004) Bridled power, 4th edn. Oxford University Press, Oxford

Radio New Zealand (2011) New Governor-General to be named soon. Radio New Zealand, 22 February

Republican Movement of Aotearoa New Zealand (2010) Submission to the Government Administration Select Committee on the Governor-General Bill

Satyanand A (2010a) We the people(s): opening address, In Charters C, Knight Dean R (eds), we the people(s): participation in governance. Victoria University Press, Wellington

Satyanand A (2010b) The Governor-General's role. www.gg.govt.nz/node/3076.

Smith P (2008) Key knocking on door of government. Financial Times, 1 September 
Stockley AP (1996a) Becoming a republic: matters of symbolism. In: Trainor L (ed) Republicanism in New Zealand. Dunmore Press, Palmerston North, p 61

Stockley AP (1996b) Becoming a republic? Issues of law. In: Trainor L (ed) Republicanism in New Zealand. Dunmore Press, Palmerston North, p 81

Stockley AP (1996c) Parliament, Crown and Treaty: inextricably linked? NZ Univ Law Rev 17:193

Stockley AP (1998) Of conventions and constitutional change: lessons for New Zealand. Univ N S W Law J: 21:936

The Dominion (2002) Republic inevitable: PM. The Dominion (25 February 2002)

Tizard C (1993) Crown and anchor: the present role of the Governor-General in New Zealand. www.gg.govt.nz/node/565

Townend A (2003) The strange death of the realm of New Zealand: the implications of a New Zealand republic for the Cook Islands and Niue. Victoria University of Wellington Law Rev $34: 571$ 